\title{
New plant records for Tankwa Karoo National Park, South Africa
}

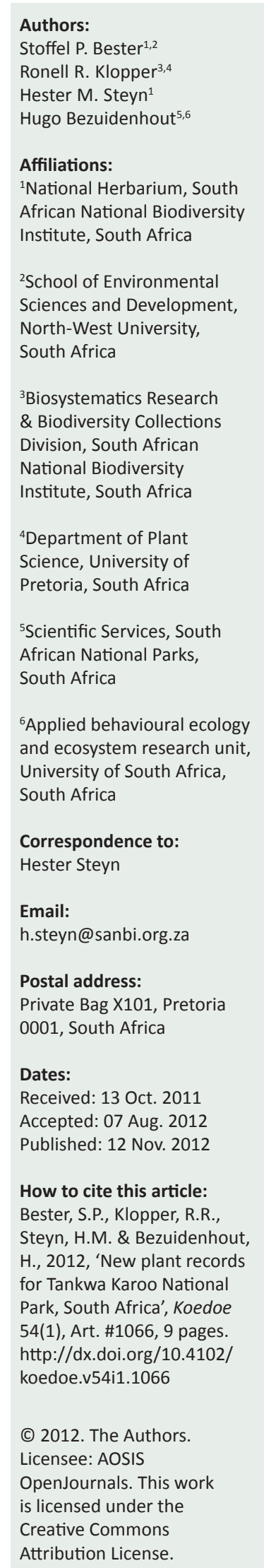

The Tankwa Karoo National Park has been enlarged from 27064 ha to 143600 ha. This whole area is severely under-collected for plants in general and therefore it was an obvious target for the South African National Parks (SANParks) Programme, a component of the Pretoria National Herbarium (PRE) Plant Collecting Programme. This programme not only aims to survey national parks that have been poorly surveyed, but also inadequately known taxa, unique habitats, remote and inaccessible areas and plant species flowering at irregular times, especially after events such as fire or unusual timing of, or high, rainfall. General collecting in the Tankwa Karoo National Park has already led to the description of two new taxa, from two families. It furthermore resulted in new distribution records for the park and for the Northern Cape Province. These are reported on here.

Conservation implications: Although the Tankwa Karoo National Park falls within the Succulent Karoo Biome (a biodiversity hotspot of international importance), information on its plant diversity is insufficient because it is an under-collected area. Results of this study will guide conservation and supply occurrence and distribution data required to compile management plans for the park.

\section{Introduction}

The Tankwa Karoo National Park (TKNP) is a relatively new addition to South Africa's treasure of National Parks and was only declared a national park in 1986 (Rubin 1998). The original park consisted of eight farms amounting to 27064 ha, which comprised mainly long gentle slopes to low-lying plains and isolated hills (Rubin 1998). By 2011 the park was extended to 143600 ha.

The South Africa National Parks (SANParks) plant collection programme is a facet of the larger National Herbarium (PRE) Plant Collecting Programme, where priority is given to collecting in national parks that contain under-collected areas (less than 200 species known within a quarter degree squared [QDS] grid according to the South African National Biodiversity Institute [SANBI]'s plant database PRE Computerised Information System [PRECIS]). This programme officially started in 2005 with collecting efforts in the Tankwa Karoo and Namaqua National Parks. The work within these parks not only targets the under-collected areas, but also inadequately known taxa, unique habitats, remote and inaccessible areas and plant species flowering at irregular times, especially after events such as fire or unusually high rainfall. The aim of such surveys in under-collected areas, such as the TKNP, is to enhance our knowledge and general understanding of these conservation areas in terms of their floristic component. General collecting in these areas will enable us to compile comprehensive species checklists for the areas that will, in turn, inform decisions regarding the conservation and monitoring of these conservation areas and the plants which they contain.

\section{Research method and design}

Tankwa Karoo National Park is situated in the southern section of the Succulent Karoo Biome (Mucina \& Rutherford 2006) and stretches from the plains in the south-west to the escarpment of the Roggeveld Mountains in the east (Figure 1). For details on the vegetation of the Tankwa Karoo and the TKNP in particular the reader is referred to Rubin (1998 [for major plant communities]), Van der Merwe, Van Rooyen and Van Rooyen (2008a [Fynbos related vegetation]) and Van der Merwe, Van Rooyen and Van Rooyen (2008b [Succulent Karoo vegetation]).

All the QDS grids in the park are regarded as under-collected, and therefore the whole park was targeted for general collecting. This entails collecting herbarium specimens of all plants that are flowering or fruiting at the various collecting sites that were chosen. Collecting sites were selected to represent the variety of habitat types, for example hill slopes, plains and so forth, found within the specific QDS. Collecting trips targeted different areas of the park and were carried out at various times of the year (July-October), to reflect the floristic component of the park as best as possible.

A total of seven collecting trips were conducted within the park in 2005-2010 with collecting efforts concentrated in the six QDSs that comprised the park in 2005. The collecting was carried 
out by 10 collectors (all staff of the National Herbarium in Pretoria), including the first three authors. Most trips included two or three collectors at a time, with one large trip where six collectors were involved.

Information accompanying each specimen includes the standard information recorded on herbarium collecting labels, such as locality, habitat, substrate, lithology, exposure, aspect and slope. Global positioning system (GPS) readings were taken, but these mostly represent a few general readings for a collecting site as a whole, and are not necessarily specific for each individual plant collected.

Fertile herbarium specimens were collected and identified mainly at the National Herbarium in Pretoria (PRE). Cuttings were taken from sterile stapeliads and these were grown at the Pretoria National Botanical Garden's nursery until flowering. Flowers were then added to the herbarium sheets with sterile stems. Specimens are housed at PRE and duplicates, when available, were distributed to the Kimberley South African National Parks Herbarium (KSAN), the Compton Herbarium in Cape Town (NBG), and McGregor Museum Herbarium in Kimberley (KMG). Herbarium acronyms follow Holmgren, Holmgren and Barnett (1990).

Specimen information was incorporated into the main database, the Pretoria National Herbarium (PRE) Computerised Information System (PRECIS), to allow analysis of distribution data. New specimen records were compared to existing records in PRECIS. Where a first record for a taxon in TKNP was indicated, the existing checklist for the area (Rubin 1998) was consulted to verify the novelty of the record. All relevant specimens acting as vouchers of the new records reported on here, are cited under each taxon in Appendix 1. The citation of these voucher specimens are listed in the following format: PROVINCE.- Grid latitude and longitude (Grid name): Locality description where the specimen was collected (-QDS indicator), Date, Collector $\mathcal{E}$ collector's number (Acronym of herbaria where the specimen and its duplicates are housed)

\section{Ethical considerations}

Ethical consideration has been given to the collection of plant specimens by not collecting indiscriminately and taking care not to damage plants.

\section{Results and discussion}

During recent field trips targeting the Tankwa Karoo region and especially the TKNP, approximately 1500 specimens were collected by staff from the National Herbarium (PRE). This substantially increased our knowledge of the floristics of the region: at the start of the programme the lowest number of species per QDS was 16 (3219BA); this number was raised to 108 (3219BA) by 2011 (Table 1).

Many significant collections were made as part of this programme: new distribution records were added to the PRE collection, for example Bulbine triebneri Dinter (first record for the Northern Cape, Klopper et al. 2008); first records for the park were collected, for example Dioscorea elephantipes (L'Hér.) Engl. (collected on the Gannaga Pass); a new species

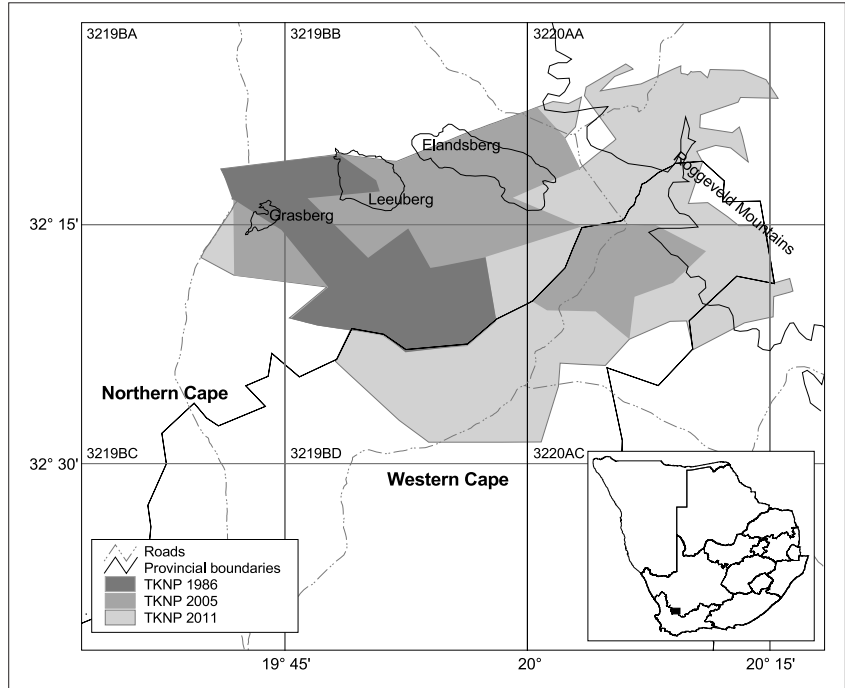

FIGURE 1: Map of Tankwa Karoo National Park showing the original boundaries of the park at its inception in 1986, the expanded park as in 2005, and its current size (2011).

TABLE 1: Number of species per Quarter Degree Square grid cell according to the Pretoria National Herbarium Computerised Information System data.

\begin{tabular}{lccc}
\hline Grid (QDS) & \multicolumn{3}{c}{ Year } \\
\cline { 2 - 4 } & $\mathbf{2 0 0 3}$ & $\mathbf{2 0 0 7}$ & $\mathbf{2 0 1 1}$ \\
\hline $3219 B A$ & 16 & 17 & 108 \\
$3219 B B$ & 27 & 158 & 272 \\
$3219 B C$ & 25 & 28 & 115 \\
$3219 B D$ & 32 & 145 & 170 \\
$3220 A A$ & 34 & 274 & 449 \\
$3220 A C$ & 22 & 168 & 227 \\
\hline
\end{tabular}

Source: Pretoria National Herbarium Computerised Information System QDS, Quarter Degree Square.

TABLE 2: Family, taxon and status of new plant distribution records from Tankwa Karoo National Park.

\begin{tabular}{|c|c|c|}
\hline Family & Taxon & Status \\
\hline \multirow[t]{6}{*}{ Apocynaceae } & Quaqua acutiloba & New record for TKNP \\
\hline & $\begin{array}{l}\text { Quaqua parviflora subsp. } \\
\text { gracilis }\end{array}$ & New record for TKNP \\
\hline & Stapelia arenosa & New record for TKNP \\
\hline & Stapelia surrecta & New record for TKNP \\
\hline & $\begin{array}{l}\text { Tridentea parvipuncta subsp. } \\
\text { truncata }\end{array}$ & New record for TKNP \\
\hline & Tromotriche thudichumii & New record for TKNP \\
\hline \multirow[t]{3}{*}{ Asphodelaceae } & Aloe falcata & New record for TKNP \\
\hline & Aloe microstigma & New record for TKNP \\
\hline & Aloe variegata & New record for TKNP \\
\hline Hyacinthaceae & Lachenalia ameliae & $\begin{array}{l}\text { New record for TKNP and } \\
\text { Northern Cape }\end{array}$ \\
\hline Iridaceae & Moraea tanquana & $\begin{array}{l}\text { Range extension within } \\
\text { TKNP }\end{array}$ \\
\hline Scrophulariaceae & Nemesia suaveolens & $\begin{array}{l}\text { Range extension within } \\
\text { TKNP }\end{array}$ \\
\hline \multirow{3}{*}{$\begin{array}{l}\text { Pteridophyta: } \\
\text { Sinopteridaceae }\end{array}$} & Cheilanthes induta & New record for TKNP \\
\hline & Cheilanthes namaquensis & New record for TKNP \\
\hline & Cheilanthes parviloba & $\begin{array}{l}\text { New record for TKNP and } \\
\text { Northern Cape }\end{array}$ \\
\hline
\end{tabular}

TKNP, Tankwa Karoo National Park.

(Moraea tanquana Goldblatt \& J.C.Manning) was described from Leeuberg (Goldblatt \& Manning 2009) and a new monotypic genus in the Apiaceae (Scaraboides Magee \& B.-E. van Wyk) was described from Elandsberg (Magee et al. 2009).

Further significant range extensions and new park and provincial records from within the park are provided (Table 2) with additional information on each species (Appendix 1). 

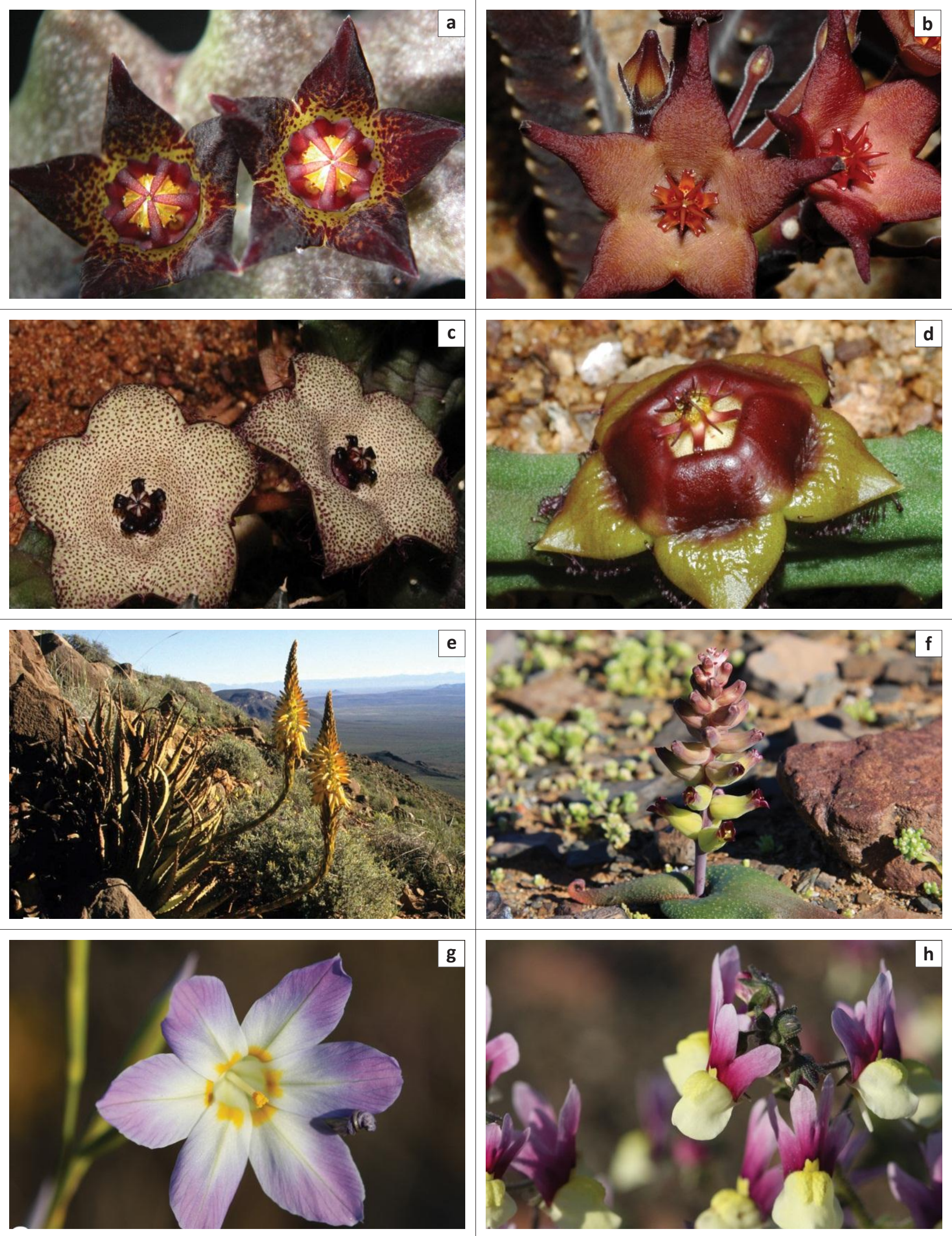

Source: Photo (a-d), S.P. Bester; Photo (e), R.R. Klopper; Photo (f-h), M. Koekemoer

FIGURE 2: Images of selected species reported on: (a) Quaqua acutiloba, (b) Stapelia surrecta, (c) Tridentea parvipuncta subsp. truncata, (d) Tromotriche thudichumii, (e) Aloe microstigma growing on the Gannaga Pass, (f) Lachenalia ameliae growing on gravel plain, (g) Moraea tanquana and (h) Nemesia suaveolens. 
In the checklist of species for the TKNP (Rubin 1998) only two stapeliads were listed, namely Hoodia gordonii (Masson) Sweet ex Decne. and a Stapelia species. Stapeliads, in general, are poorly represented in herbaria because it is usually difficult to locate these plants. Many are obscured and hidden amongst nurturing plants that provide shade and shelter or they may grow in inaccessible habitats. Furthermore, because of their collector's value, many plants are collected and kept in living collections without making representative herbarium specimens. The correct preservation of herbarium specimens of Stapeliads is also perceived to be difficult. Cuttings collected in the park were grown until they flowered which made positive identification possible - the list was extended to include six more taxa (Table 2).

No aloes (Asphodelaceae) or ferns (Pteridophyta) were represented on the previous checklist (Rubin 1998) and general collecting led to three taxa being added from each of these plant groups (Table 2). Although records of Aloe microstigma Salm-Dyck from the Calvinia area has been known since the 1920s, this species has not been collected in the TKNP until 2006 when a few individuals of this aloe were found growing on the Gannaga Pass.

Apart from Moraea tanquana (Vulnerable) and Nemesia suaveolens K.E.Steiner (Rare), the only other taxon with a Red List status of conservation concern is Lachenalia ameliae W.F.Barker (Near Threatened) (L. von Staden pers. comm., February 2010). Following the new records and range extensions resulting from this study, the extent of occurrence could be re-determined and the statuses of these species were revised. All other taxa reported on here are listed in the latest Red List (Raimondo et al. 2009) as Least Concern, and these new records have no influence on their status.

\section{Conclusion}

The general collecting carried out thus far in the TKNP has increased our knowledge of the flora of a severely undercollected and unique habitat significantly. Knowledge of the full distribution of taxa, especially taxa with limited distribution ranges, is imperative in helping us fully understand these plant species; for instance, without this information the assessment of Red Data List status of such taxa cannot be carried out accurately. Data generated by the SANParks Programme in TKNP will be used for better informed decisions regarding the conservation of this unique area and also will assist SANParks with management of these plant species. The data are essential in conservation and monitoring actions within the park and will be taken up in the Park Management Plan and Conservation Development Framework. Furthermore, it is useful in terms of ecotourism to show visitors which species occur in the park and to highlight the importance of the park in the conservation of these plants. The occurrence of rare and threatened plants in the TKNP will also focus the attention of researchers working on these groups on the park and will thus stimulate further research in the area.

\section{Acknowledgements}

We would like to thank our colleagues for helpful comments and suggestions on this manuscript. Cape Nature and Northern Cape Nature Conservation provided collecting permits, and Lize von Staden assessed the threat status of species. We also acknowledge with appreciation the two anonymous referees for suggesting improvements to the manuscript. Furthermore, we would like to thank SANParks for permission to work in the Arid Parks with a special mention of Conrad Strauss, Letsie Coetzee and the staff of Tankwa Karoo National Park.

\section{Competing interests}

The authors declare that they have no financial or personal relationship(s) which may have inappropriately influenced them in writing this paper.

\section{Authors' contributions}

S.P.B. (South African National Biodiversity Institute), R.R.K. (South African National Biodiversity Institute) and H.M.S. (South African National Biodiversity Institute) were equally responsible for data collection and analyses used in this study, as well as compiling the manuscript. H.B. (South African National Parks) provided the team with logistical support for field work and made valuable contributing comments and improvements to the manuscript.

\section{References}

Brown, N.E., 1909, 'Stapelia surrecta', in W.T. Thiselton-Dyer (eds.), Flora capensis, vol 4(1), pp. 970-971, Reeve, London.

Bruyns, P.V., 2005, Stapeliads of southern Africa and Madagascar, vol. II, Umdaus Press, Hatfield.

Crouch, N.R., Klopper, R.R., Burrows, J.E. \& Burrows, S.M., 2011, Ferns of southern Africa: A comprehensive guide, Struik, Cape Town.

Goldblatt, P. \& Manning, J.M., 2009, 'New species of Moraea (Iridaceae: Iridoideae), with range extensions and miscellaneous notes for southern African species', Bothalia 39, 1-10.

Holmgren, P.K., Holmgren, N.H. \& Barnett, L.C., 1990, Index herbariorum, part 1: The herbaria of the world, 8th edn., New York Botanical Garden, New York.

Klopper, R.R., Klopper, A.W., Baijnath, H. \& Smith, G.F., 2008, 'Bulbine triebneri, an earlier name for Bulbine alba, as well as additional and new localities in Eastern and Northern Cape, South Africa', Bothalia 38, 67-69.

Klopper, R.R. \& Smith, G.F., 2007, 'The genus Aloe (Asphodelaceae: Alooideae) in Namaqualand, South Africa', Haseltonia 13, 38-51. http://dx.doi. org/10.2985/1070-0048(2007)13[38:TGAAAl]2.0.CO;2

Klopper, R.R. \& Smith, G.F., 2010, 'The genus Aloe L. (Asphodelaceae: Alooideae) in the Eastern Cape Province of South Africa', Haseltonia 16, 16-53. http://dx.doi. org/10.2985/1070-0048-16.1.16

Leach, L.C., 1985, A revision of Stapelia L. (Asclepiadaceae), Excelsa Taxonomic Series No. 3, Aloe Books, Johannesburg.

Magee, A.R., Van Wyk, B.-E., Tilney, P.M. \& Downie, S.R., 2009, 'Generic delimitations and relationships of the Cape genera Capnophyllum, Dasispermum, and Sonderina, the North African genera Krubera and Stoibrax, and a new monotypic genus of the subfamily Apioideae (Apiaceae)', Systematic Botany 34(3), 580-594. genus of the subfamily Apioideae (Apiaceae)', 'System
$\mathrm{http}: / / \mathrm{dx}$.doi.org/10.1600/036364409789271218

Mucina, L. \& Rutherford, M.C. (eds.), 2006, The vegetation of South Africa, Lesotho and Swaziland, Strelitzia 19, South African National Biodiversity Institute, Pretoria.

Raimondo, D., Von Staden, L., Foden, W., Victor, J.E., Helme, N.A., Turner, R.C. et al. (eds.), 2009, Red List of South African plants, Strelitzia 25, South African National Biodiversity Institute, Pretoria.

Rubin, F., 1998, 'The physical environment and major plant communities of the Tankwa Karoo National Park', Koedoe 41, 61-94.

Steiner, K., 2009, 'Two new species of Nemesia (Schrophulariaceae) from arid areas of the Northern Cape, South Africa', Bothalia 39, 67-72.

Van der Merwe, H., Van Rooyen, M.W. \& Van Rooyen, N., 2008a, 'Vegetation of the Hantam-Tanqua-Roggeveld subregion, South Africa. Part 1: Fynbos Biome related vegetation', Koedoe 50(1), 61-71.

Van der Merwe, H., Van Rooyen, M.W. \& Van Rooyen, N., 2008b, 'Vegetation of the Hantam-Tanqua-Roggeveld subregion, South Africa. Part 2: Succulent Karoo Biome related vegetation', Koedoe 50(1), 160-183.

Appendix 1 starts on next page $\rightarrow$ 


\section{Appendix 1: Detailed information and relevant specimens for new plant records from Tankwa Karoo National Park}

\section{Apocynaceae \\ Quaqua acutiloba (N.E.Br.) Bruyns}

This species was discovered by Robert Templeman in 1898 and described by N.E. Brown in 1909 (Bruyns 2005). Quaqua acutiloba has a relatively wide distribution range, occurring from south of Laingsburg on the edge of the western escarpment northwards to the vicinity of Aus in Namibia (Figure A-1). In the TKNP this species is associated with rocky and gravelly plains and foot slopes of hills, but also grows on the lower plateaux (for instance the Elandsberg plateau). These plants are usually associated with various species of Ruschia which, in most cases, act as nurturing plants to this species (Bruyns 2005). The stems can become $\pm 2 \mathrm{~cm}$ in diameter (usually 4-angled) and up to $300 \mathrm{~mm}$ long. The plants form clumps of up to $0.3 \mathrm{~m}$ in diameter. The flowers are about $1 \mathrm{~cm}$ in diameter and are extremely variable in the expression of colour that ranges from plain yellow-green to dark maroon with various degrees of maroon-spotted on yellow-green background forms. The flowers are open, rotate, sometimes with a shallow basal cup (Figure 2a).

Relevant specimens: NORTHERN CAPE.-3219 (Wuppertal): TKNP. Plato above Elandsberg (-BB), 07 August 2007, S.P. Bester 7792 (PRE); On the road between Potkleiberg and Pramberg. South-western foot slopes and flats at Potkleiberg. Farm: Folmoesfontein (-BD), 05 August 2007, S.P. Bester 7731 (PRE), S.P. Bester 7732 (PRE).

\section{Quaqua parviflora (Masson) Bruyns subsp. gracilis (C.A.Lückh.) Bruyns}

The material from which Lückhoff described this taxon was collected between Calvinia and Pakhuis Pass (Bruyns 2005). Compared to the previous species the flowers in Quaqua parviflora subsp. gracilis are much smaller and the stems generally much thinner. The flowers are characteristic with long narrow segments that are constricted more or less in the middle, ending in a thickened apical part. The apical section is usually homogenous in colour in contrast to the rest of the corolla that are maroon-spotted on a cream background. Based mainly on this apical swelling and somewhat longer segments of the corolla, it is possible to distinguish it from the typical subspecies. This taxon has a much more restricted distribution than the typical species, occurring from the Ceres Karoo north-westwards to the west of Garies (Figure A-1). Plants are usually confined to the lower foot slopes of mountainous areas along the escarpment in stony and rocky soils.

Relevant specimens: NORTHERN CAPE.-3220 (Sutherland): TKNP. Langkloof Gorge (-AA), 07 August 2006, S.P. Bester 7139 (PRE).

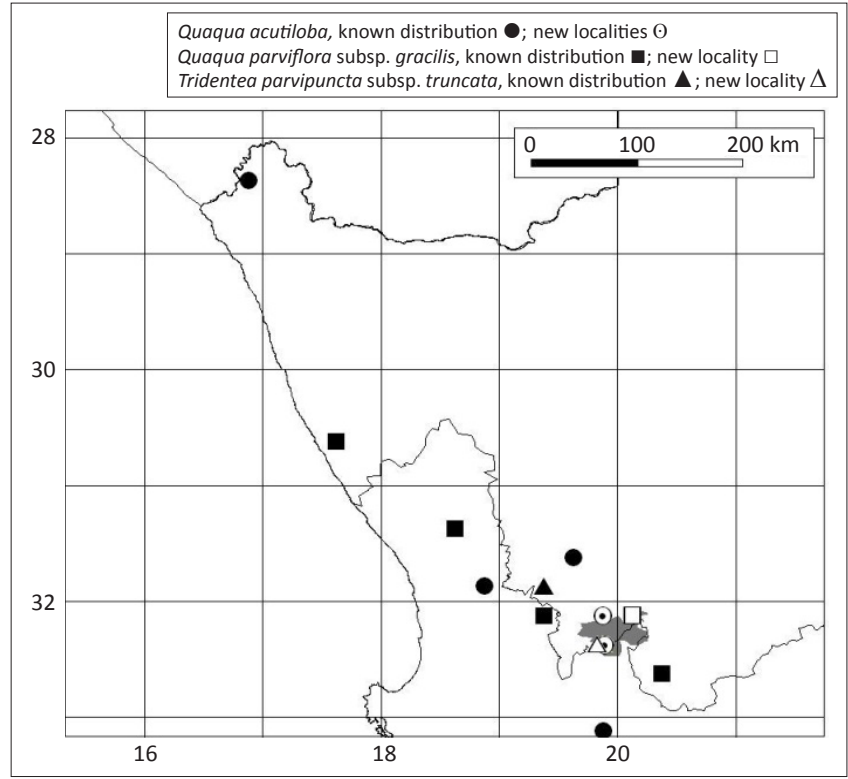

Source: Pretoria National Herbarium Computerised Information System (PRECIS) and original data The solid symbols are existing records from PRECIS, whilst the open symbols are new localities reported on.

FIGURE A-1: Distribution of Quaqua acutiloba, Quaqua parviflora subsp. gracilis and Tridentea parvipuncta subsp. truncata.

In the TKNP Quaqua and Stapelia can be distinguished from each other in the sterile state based on the hairiness of the stems. In Quaqua the stems are always glabrous compared to Stapelia where it is velvety pubescent (there are, however, some exceptions in Stapelia that are also glabrous, but these do not occur in TKNP).

\section{Stapelia arenosa C.A.Lückh.}

Joseph Archer was the first to collect this species which came from the northern Cederberg. It was later described by C.A. Lückhoff (Bruyns 2005). In the distribution range of this species it is encountered only sporadically. It has been recorded from the Kamiesberg southwards to the Karoo Poort in the Ceres Karoo (Leach 1985) (no specimens in the database). In August 2007 it was collected in the Elandsberg area (Figure A-2). The plants form few-flowered inflorescences with short pedicels causing the flowers to be held quite close to the stems. With repeated formation of flowers in inflorescences the stem may become irregularly thickened. As the stems develop, flowers may occur all along the stem, from its base to the tips. The stems are diffuse and form lax clumps.

Relevant specimens: NORTHERN CAPE.-3219 (Wuppertal): TKNP. Southern slopes of Elandsberg, (-BB), 06 August 2007, S.P. Bester 7749a (KSAN, PRE); Plato above Elandsberg, (-BB), 07 August 2007, S.P. Bester 7795b (KMG, KSAN, NBG, PRE).

\section{Stapelia surrecta N.E.Br.}

This species was first collected by Rudolph Marloth and later described by N.E. Brown in Flora capensis (1909). Stapelia surrecta (Figure $2 b$ ) is one of few species in the genus that carries flowers with long pedicels concentrated at the tips of the stems (another example is some forms of Stapelia 
kwebensis). This species has a restricted range and is only known from the Ceres Karoo. It occurs from Karoo Poort in the south to Bloukrans Pass in the north (Figure A-2). In the TKNP plants were collected in rocky and sandy soils in the Langkloof, but according to Bruyns (2005) it is restricted to shale and tillite. This species can only be distinguished from Stapelia arenosa when flowering because the vegetative stems are indistinguishable.

Relevant specimens: NORTHERN CAPE.-3220 (Sutherland): TKNP. Langkloof Gorge (-AA), 07 August 2006, S.P. Bester 7161a (KSAN, PRE); 7163a (PRE).

\section{Tridentea parvipuncta (N.E.Br.) L.C.Leach subsp. truncata (C.A.Lückh.) Bruyns}

The subspecies was originally discovered by James Lückhoff in 1931 and described by C.A. Lückhoff in 1937 (Bruyns 2005). It is distinguished from the typical subspecies in that the outer corona lobes are truncate and emarginate and not deeply bifid with two lobes diverging as in the typical subspecies (Figure 2c). Tridentea parvipuncta subsp. truncata are found from the western section of Karoo Poort to Botterkloof (Figure A-1). It is separated from the typical subspecies which is found south of Merweville westwards.

Relevant specimens: NORTHERN CAPE.-3219 (Wuppertal): TKNP. On the road between Potkleiberg and Pramberg. South-western foot slopes and flats at Potkleiberg. Farm: Folmoesfontein (-BD), 07 November 2007, S.P. Bester 7730a (KMG, KSAN, PRE).

\section{Tromotriche thudichumii (Pillans) L.C.Leach}

Although this taxon was already discovered in 1937 and re-collected in 1940 by Marthinus Malherbe, it was only described some 20 years later by N.S. Pillans in 1959 (Bruyns 2005). Despite a manuscript name that was given to it in the Bolus Herbarium (Stapelia malherbei), it was eventually named after Jacques Thudichum (curator of the Karoo Botanical Garden at the time), who found a number of these plants in cultivation at the garden which he could not identify. The plants grow in rocky and gravelly soils on the flats of the Tanqua Karoo and Roggeveld escarpment (Bruyns 2005), mainly in the Ceres Karoo (north of Karoo Poort) and Calvinia Districts (Figure A-2). Characteristic of this species is the corolla that is so strongly reflexed that the flowers usually seem to be clasping the stem (Figure 2d).

Relevant specimens: NORTHERN CAPE.-3219 (Wuppertal): TKNP. Southern slopes of Elandsberg (-BB), 06 August 2007, S.P. Bester 7749 (KMG, KSAN, PRE); Plato above Elandsberg, (-BB), 07 August 2007, S.P. Bester 7795a (KMG, KSAN, PRE); On the road between Potkleiberg and Pramberg. The south-western foot slopes and flats at Potkleiberg. Farm: Folmoesfontein (-BD), 05 August 2007, S.P. Bester 7730 (PRE).

\section{Asphodelaceae: Alooideae Aloe microstigma Salm-Dyck}

Aloe microstigma occurs fairly widespread in the western parts of the Eastern Cape, the central areas of the Western
Cape and just into the Northern Cape, with a disjunction to south-western Namibia (Klopper \& Smith 2010). Although records from the Calvinia area has been known since the 1920s, this species has not been collected in the TKNP until 2006 when a few individuals of this aloe were found growing on steep slopes in Tankwa Escarpment Shrubland (Mucina \& Rutherford 2006) on the Gannaga Pass. This population represents the yellow flowering form of A. microstigma, previously known as Aloe brunthallerii A.Berger ex Cammerl. and is one of the northernmost records of this colour form (Figure 2e and Figure A-3).

Relevant specimens: NORTHERN CAPE.-3220 (Sutherland): TKNP, top of Gannaga Pass, Farm Kleinfontein 1027, near the

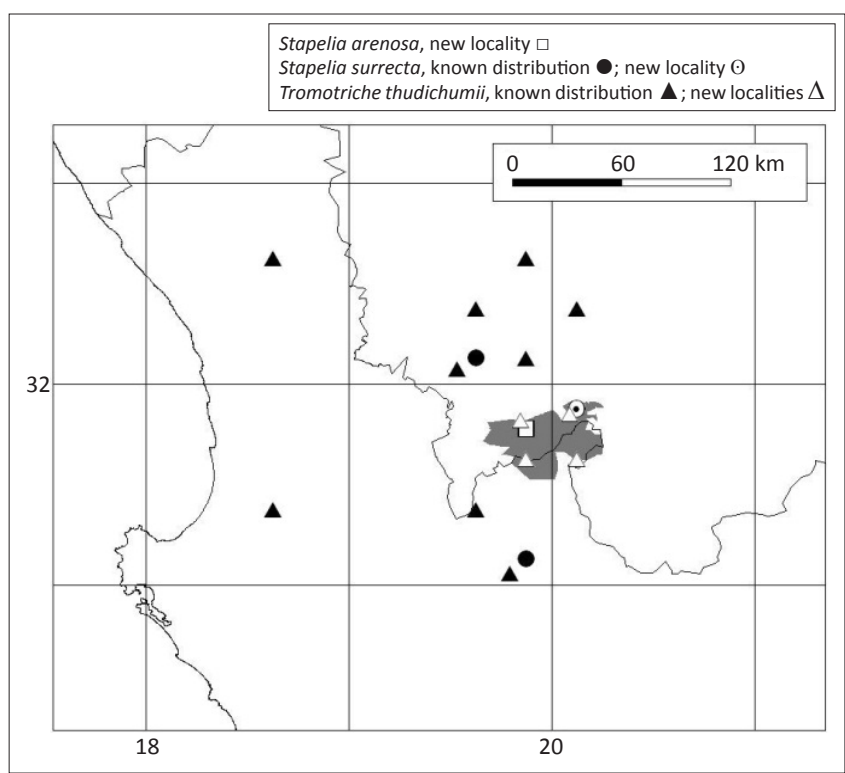

Source: Pretoria National Herbarium Computerised Information System (PRECIS) and original data The solid symbols are existing records from PRECIS, whilst the open symbols are new localities reported on.

FIGURE A-2: Distribution of Stapelia arenosa, Stapelia surrecta and Tromotriche thudichumii.

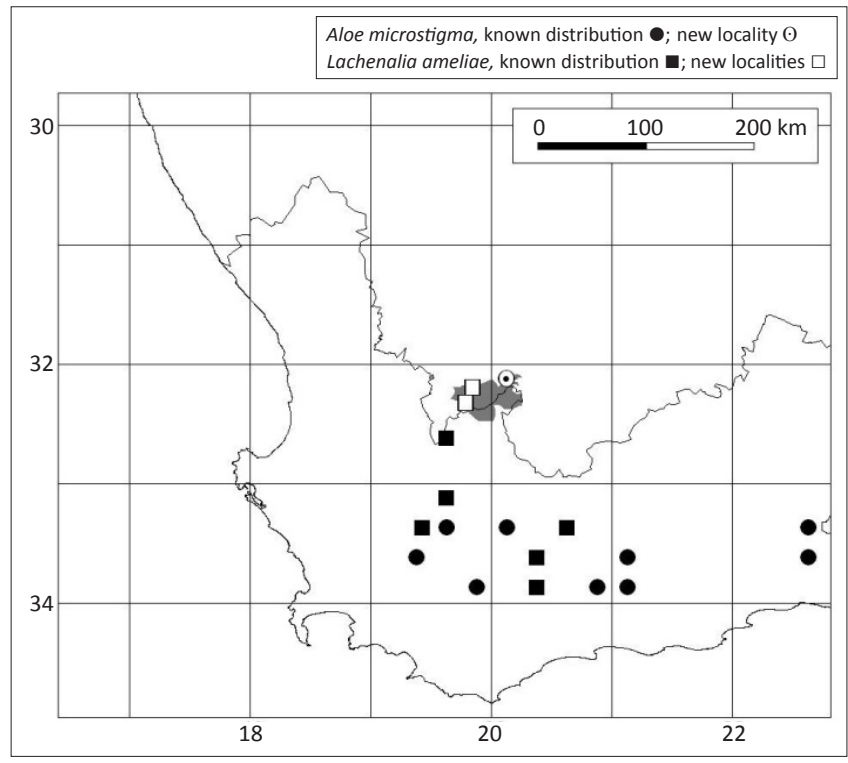

Source: Pretoria National Herbarium Computerised Information System (PRECIS) and original data The solid symbols are existing records from PRECIS, whilst the open symbols are new localities reported on.

FIGURE A-3: Distribution of Aloe microstigma and Lachenalia ameliae. 
viewpoint, (-AA), 05 August 2006, R.R. Klopper 321 (KSAN, PRE); 10 July 2010, R.R. Klopper E A.W. Klopper $336 \mathcal{E} 337$ (PRE).

\section{Aloe falcata Baker}

Aloe falcata is known to occur from the Richtersveld south to the Klawer area and inland to around Calvinia (Klopper $\&$ Smith 2007). It was first observed on a rocky ridge in the Tanqua Karoo vegetation type (Mucina \& Rutherford 2006) during a general collecting trip in TKNP in August 2006, but was not in flower and no material was collected. The significance of this population was only realised afterwards: it is the most south-eastern record known for this aloe to date. Subsequently, during a specialised collecting trip focussing on aloes in 2010, a herbarium record from this population was collected (Figure A-4).

Relevant specimens: NORTHERN CAPE.-3220 (Sutherland): TKNP, Farm Roodewerf 1091, Houtkraalkloof, (-AA), 10 July 2010, R.R. Klopper E A.W. Klopper 339 (PRE).

\section{Aloe variegata $L$.}

This very widespread and small aloe, with its cryptically mottled and camouflaged leaves (Klopper \& Smith 2007, 2010), is very inconspicuous when not in flower. It is thus not surprising that it has not been collected in the TKNP before 2006, even though it occurs at several localities within the park, all within the Tanqua Karoo vegetation type of the Rainshadow Valley Karoo Bioregion (Mucina \& Rutherford 2006) (Figure A-5).

Relevant specimens: NORTHERN CAPE.-3219 (Wuppertal): TKNP, hill east of Leeuberg, (-BB), 04 August 2006, H.M. Steyn 888 (KSAN, PRE); Grasberg South 1103, (-BC), 16 August 2008, H.M. Steyn 1457 (PRE); Foot of slope west of Potklysberg, (-BD), 05 August 2007, A.C. Mudau 254 (PRE). 3220 (Sutherland): TKNP, border of farms Manus Zyn Dam and Roodewerf 1019, Remhoogte, (-AA), 08 August 2006, R.R. Klopper 361 (KSAN, PRE); Maansedam, on the plain surrounding the house, south of the house, (-AA), 06 August 2006, H.M. Steyn 941 (KSAN, PRE).

\section{Hyacinthaceae}

\section{Lachenalia ameliae W.F.Barker}

Lachenalia ameliae was thought to be endemic to the Western Cape, occurring mainly in the Montagu and Touws River areas. The northernmost specimen was collected in 1921 at Gansfontein in the Ceres Karoo (Marloth 10479, PRE). During August 2006, 2008 and 2011 four populations were found in three adjacent grids in the north-western parts of TKNP. These populations comprise several plants growing on shalederived soils on gravel plains in the Tanqua Karoo vegetation type (Mucina \& Rutherford 2006), at altitudes between $352 \mathrm{~m}$ and $407 \mathrm{~m}$. This represents a northward extension of the known distribution range by $\pm 50 \mathrm{~km}$ and a new record for the Northern Cape (Figure $2 \mathrm{f}$ and Figure A-3). Because of the new records, the extent of occurrence changed from $4000 \mathrm{~km}^{2}$ to $17696 \mathrm{~km}^{2}$, but this is still within the Near Threatened (NT) range and the status remains unchanged (L. von Staden pers. comm., February 2012).

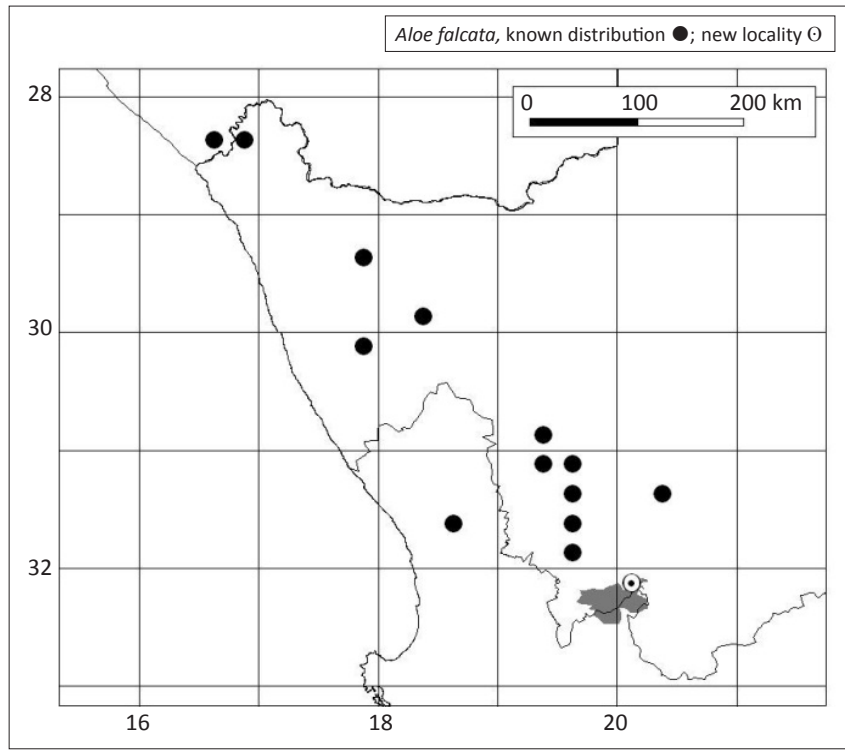

Source: Pretoria National Herbarium Computerised Information System (PRECIS) and original data The solid symbols are existing records from PRECIS, whilst the open symbols are new localities reported on.

FIGURE A-4: Distribution of Aloe falcata.

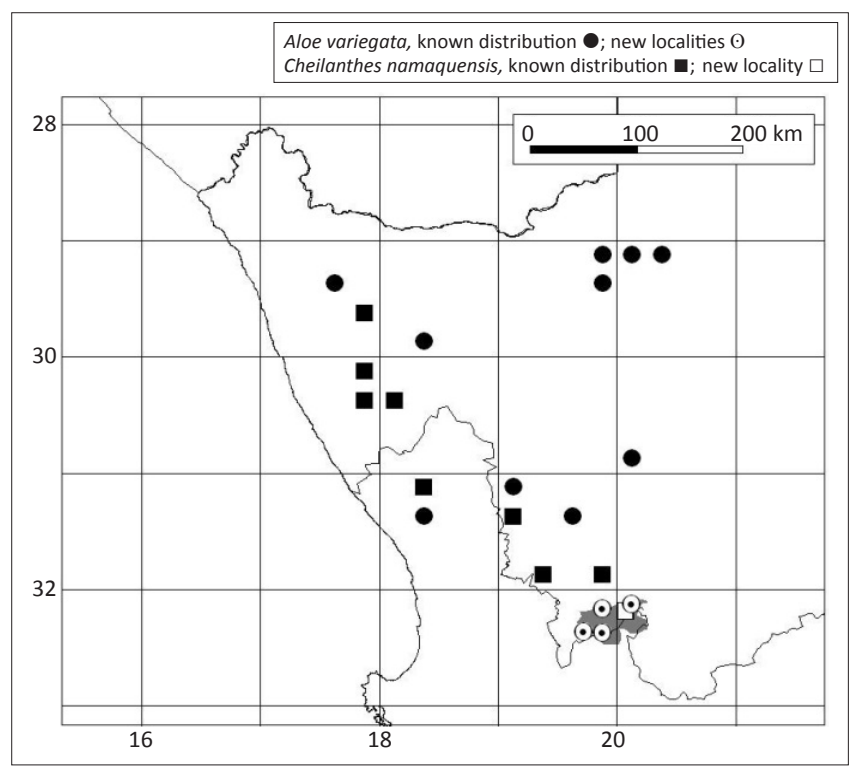

Source: Pretoria National Herbarium Computerised Information System (PRECIS) and original data The solid symbols are existing records from PRECIS, whilst the open symbols are new localities reported on.

FIGURE A-5: Distribution of Aloe variegata and Cheilanthes namaquensis.

Relevant specimens: NORTHERN CAPE.-3219 (Wuppertal): TKNP. Sandy wash West of Leeuberg, (-BB), 03 August 2006, H.M. Steyn $863 b$ (PRE); TKNP, between Varsfontein and Prambergfontein, (-BB), 17 August 2008, H.M. Steyn 1459 (KSAN, PRE); TKNP, Grasberg South 1103, (-BC), 16 August 2008, H.M. Steyn 1452 (KSAN, PRE); TKNP, track between Luiperdskop and Varsfontein, (-BD), 15 August 2011, H.M. Steyn 1864 (PRE).

\section{Iridaceae}

\section{Moraea tanquana Goldblatt \& J.C.Manning}

As a result of general collecting, a previously unknown, blue flowering Moraea species was collected in TKNP in August 2006 (Figure 2g). It was subsequently described as 
M. tanquana (Goldblatt \& Manning 2009). When described, this species was only known from the type locality, but during follow-up field trips to different parts of the park, three more populations were found. In August 2008, a population was found on the lower north-eastern slopes of Leeuberg (no specimens were collected), as well as on a plateau to the southeast of Grasberg. In August 2009, yet another population on the eastern side of the same plateau was discovered. All three populations were found in Tanqua Karoo vegetation (Mucina \& Rutherford 2006) on doleritederived stony or rocky soil. The populations were estimated to consist of between 80 and 120 plants each and the maximum range extension is between $13 \mathrm{~km}$ and $15 \mathrm{~km}$ (Figure A-6). A preliminary threatened status of VU D1 (Vulnerable) was assigned to this species based on the localised distribution and relatively small population sizes (L. von Staden pers. comm., February 2010).

Relevant specimens: TYPE.-Northern Cape, 3219 (Wuppertal): TKNP, small koppie east of Leeuberg, (-BB), 04 August 2006, H.M. Steyn 872 (NBG, holo.; KSAN, PRE, iso.).

NORTHERN CAPE.-3219 (Wuppertal): Grasberg South 1103, (-BC), 16 August 2008, H.M. Steyn 1431 (PRE); Hill west of track between Varsfontein and Luiperdskop, (-BD), 06 August 2009, H.M. Steyn 1524 (PRE).

\section{Scrophulariaceae}

\section{Nemesia suaveolens K.E.Steiner}

A number of Nemesia specimens with yellow and purple or pink flowers were collected (Figure 2h). This species was usually found on gravelly sand in the Tanqua Karoo vegetation type (Mucina \& Rutherford 2006). At the time, these specimens could not be matched to any Nemesia species at PRE and they were only recently identified as $N$. suaveolens K.E.Steiner. This is an annual species known from a very limited area of the central Tanqua Karoo. The flowers have a straight spur and a pleasant spicy fragrance (Steiner 2009). With this new information the national threatened status of this species was determined as Rare, because it has a restricted range (EOO $478 \mathrm{~km}^{2}$ ) and is potentially vulnerable to grazing and population fluctuations in response to rainfall. Subpopulations, however, are large and a large proportion of the population is protected in the TKNP (L. von Staden pers. comm., February 2010).

The known distribution of this species is shown in Figure A-6. The original localities are included in this map, not only to highlight the new records, but to rectify the original map (Steiner 2009:70). In the original map all the collections were plotted in $3219(-B C)$, although specimens were listed from (-BA), (-BC), (-BD), (-DA) and 3220 (-AC) (Steiner 2009).

Relevant specimens: NORTHERN CAPE.-3219 (Wuppertal): TKNP, Western end of park. Dry riverbed, (-BA), 02 August 2007, S.P. Bester 7687 (PRE); TKNP, between Varsfontein and the gate at the Ceres-Calvinia road, (-BA), H.M. Steyn 1434 (PRE); Calvinia District, TKNP, gravel plains west of Leeuberg, (-BB), 03 August 2006, B. Sachse 31B (PRE); Calvinia District, TKNP, Biesjesfontein (-BB), 15 August
2011, S.P. Bester 10713 (PRE); TKNP, Grasberg South 1103, (-BC), H.M. Steyn 1442 (PRE); Calvinia District, TKNP, Luiperdskop farm SE of the koppie (-BD), 15 August 2011, S.P. Bester 10712 (PRE).

WESTERN CAPE.-3220 (Sutherland): Along the road between Paulshoek and Oudebaaskraal (-AC), 05 August 2009, M. Koekemoer 3752 (PRE); Ceres District, TKNP, between Roodewerf and Oudebaaskraal, Platfontein farm (-AC), 13 August 2011, S.P. Bester 10706 (PRE).

\section{Pteridophyta: Sinopteridaceae Cheilanthes parviloba (Sw.) Sw.}

This fern is widespread from the Western Cape, through

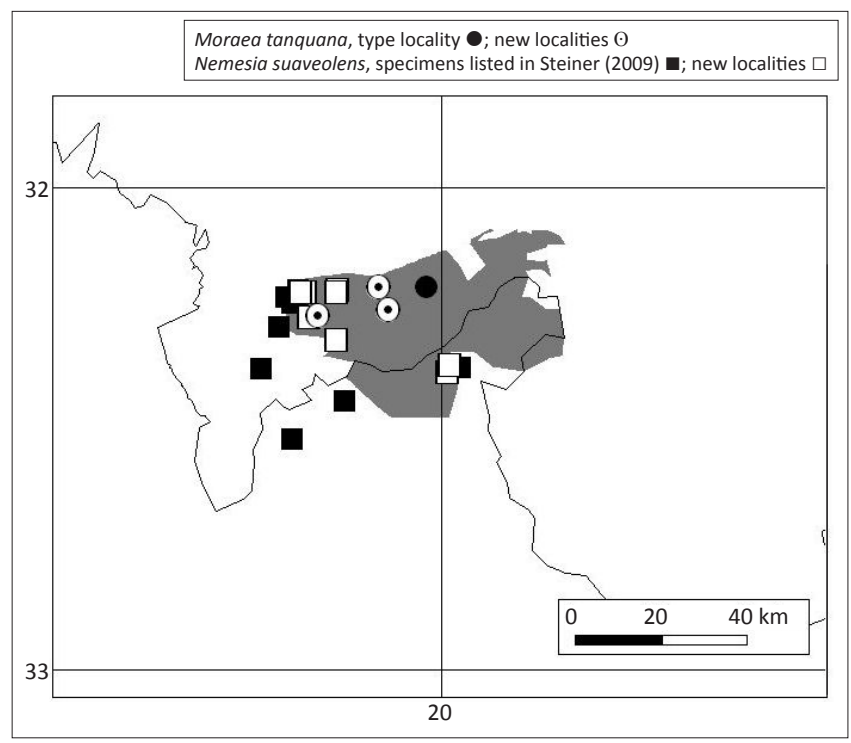

Source: Pretoria National Herbarium Computerised Information System (PRECIS) and original data The solid symbols are existing records from PRECIS, whilst the open symbols are new localities reported on.

FIGURE A-6: Distribution of Moraea tanquana and Nemesia suaveolens.

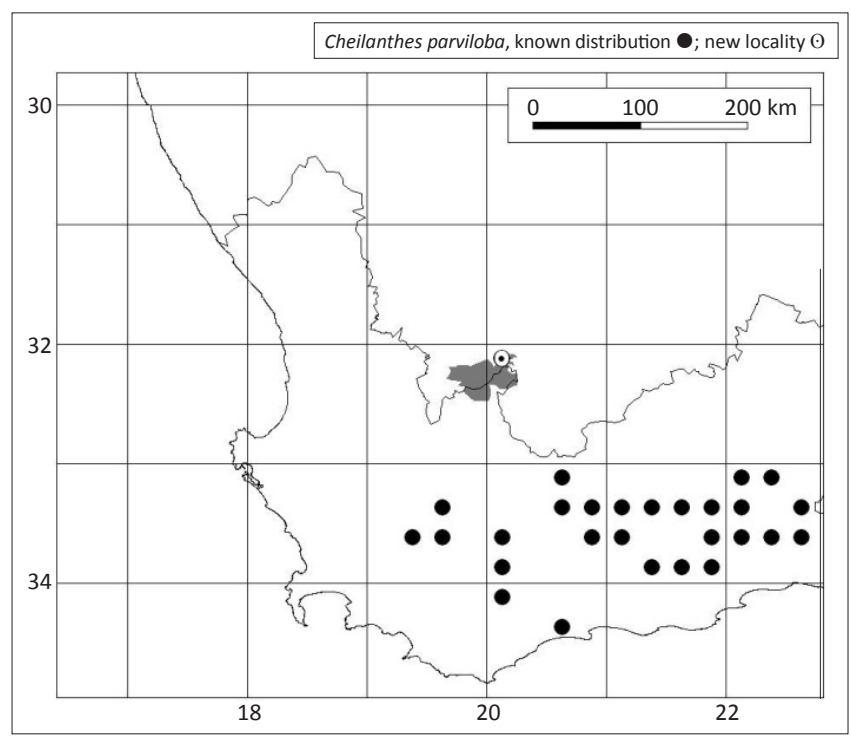

Source: Pretoria National Herbarium Computerised Information System (PRECIS) and original data The solid symbols are existing records from PRECIS, whilst the open symbols are new localities reported on.

FIGURE A-7: Distribution of Cheilanthes parviloba. 


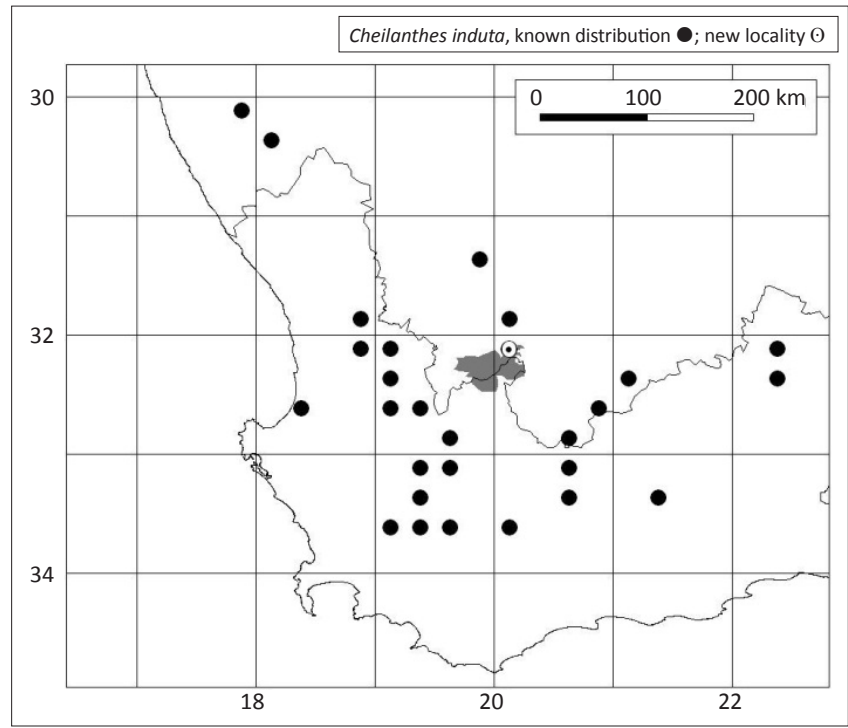

Source: Pretoria National Herbarium Computerised Information System (PRECIS) and original data The solid symbols are existing records from PRECIS, whilst the open symbols are new localities reported on.

FIGURE A-8: Distribution of Cheilanthes induta.

the Eastern Cape to the south of KwaZulu-Natal, the Free State, Lesotho, North West and Limpopo, with a disjunction to central Namibia, and also occurs in southern Zimbabwe (Crouch et al. 2011). It was first collected in the TKNP in 2006 in the Tankwa Escarpment Shrubland (Mucina \& Rutherford 2006) near the top of Gannaga Pass. It had not been collected in the Northern Cape previously; thus this collection represents a range extension of $\pm 150 \mathrm{~km}$ from the nearest known record in the Western Cape (Figure A-7).

Relevant specimens: NORTHERN CAPE.-3220 (Sutherland): TKNP, Farm Kleinfontein 1027. Plateau at top of Gannaga Pass, at the top edge of the pass, (-AA), 05 August 2006, R.R. Klopper 319 (KSAN, PRE).

\section{Cheilanthes induta Kunze}

Cheilanthes induta is a fairly distinctive species, characterised by long, reddish hairs on the stipe, rachis and abaxial lamina surface, as well as its unusual convoluted stipe (Crouch et al. 2011). It occurs widespread in the Western Cape and adjacent parts of the Northern Cape, as far north as Springbok, and the Eastern Cape, extending into the isolated mountains of the Great Karoo (Crouch et al. 2011). It was first collected in the TKNP in 2007 in the Roggeveld Shale Renosterveld (Mucina \& Rutherford 2006) (Figure A-8).

Relevant specimens: NORTHERN CAPE.-3220 (Sutherland): TKNP, Klipfontein Farm, (-AA), 14 September 2007, M.S. Mothogoane 736 (PRE).

\section{Cheilanthes namaquensis (Baker) Schelpe \& N.C.Anthony}

Cheilanthes namaquensis is a rare fern that occurs from southern Namibia, through Namaqualand in the Northern Cape, into the Western Cape (Crouch et al. 2011). It is easily confused with Cheilanthes deltoidea Kunze subsp. deltoidea that has a very similar, although slightly wider, distribution range. Cheilanthes namaquensis can be distinguished by its narrower fronds with basal pinnae that are not basiscopically developed and its rachis that is only winged in the apical portion of the frond and not winged throughout, as in the broadly triangular fronds of $C$. deltoidea with its basiscopically developed basal pinnae (Crouch et al. 2011). This fern was first collected in TKNP in 2006 in Tankwa Escarpment Shrubland (Mucina \& Rutherford 2006) (Figure A-5).

Relevant specimens: NORTHERN CAPE.-3220 (Sutherland): TKNP, Farm Langekloof 60. Langkloof, $\pm 1.5 \mathrm{~km}-2 \mathrm{~km}$ north of Malansgat River, (-AA), 07 August 2006, R.R. Klopper 353 (KSAN, PRE). 